\title{
Artikel
}

\section{0 jaar nieuw erfrecht, maar niet voor informele samenlevingspartners}

\section{Een denkraam met voorstel}

Prof. mr. F.W.J.M. Schols*

\section{Vooraf}

Al tien jaar staat in artikel 10 lid 1 van Boek 4 van het Burgerlijk Wetboek (BW) het volgende:

'De wet roept tot een nalatenschap als erfgenamen uit eigen hoofde achtereenvolgens:

a. de niet van tafel en bed gescheiden echtgenoot van de erflater tezamen met diens kinderen;

b. de ouders van de erflater tezamen met diens broers en zusters;

c. de grootouders van de erflater;

d. de overgrootouders van de erflater.'

De vraag is of wij inmiddels hier niet de informele samenlevingspartner op een of andere manier missen. Het onderwerp houdt mij zeker al tien jaar bezig, sinds het mooie rapport van Forder en Verbeke 'Gehuwd of
Prof. mr. F.W.J.M. Schols is hoogleraar aan het Centrum voor Notarieel Recht van de Radboud Universiteit Nijmegen en tevens verbonden aan ScholsBurgerhartSchols Estate Planning te Nijmegen.

1. C. Forder \& A.L.P.G. Verbeke, Gehuwd of niet: maakt het iets uit?, Antwerpen/Groningen: Intersentia 2005. niet: maakt het iets uit?' ${ }^{1,2}$ Waarom missen we de informele samenlevingspartner? Nou, de cijfers spreken boekdelen. ${ }^{3}$ Het ongehuwd samenleven is in trek; nu een op de vijf paren, straks een op de drie. Een gedeelte van deze samenlevers geeft aan ook niets te willen regelen. En kan er ook iets worden gezegd over de informele samenlevingspartners, de samenwoners 'in het wild', de groep zonder regelingen? Een groot aantal samenlevers makt geen samenlevingscontract. En ik durf de stelling aan dat daar waar er geen samenlevingscontract is

2. Zie mijn bijdrage in het in noot 1 genoemde rapport, alsmede mijn bijdragen in Tijdschrift voor Familie- en Jeugdrecht 2007, nr. 11, Theano vs. Hinrichsen, Family Act Scotland 2006, de moderne eilanden en de samenlevingspartner in het Nederlandse erfrecht, en in WPNR (2007) 6717, Erfrechtelijk chillen op de Antillen. Belangrijke erfrechtelijke vernieuwingen op de Nederlandse Antillen en Aruba; leerzaam voor Nederland. En onlangs nog in WPNR (2013) 6972, (Ex-)partners en postmortale solidariteit: een korte beschouwing over het 'erfrechtelijke alimentatierecht' en de postmortale solidariteit voor samenlevers, alsmede de reeks op <www.overleven.nl>: Erfrecht voor samenlevers, de Taxence-blog van 21 augustus 2013: Erfrechtelijke noodvoorziening voor samenlever in het wild: een voorstel (<www.taxence.nl/erfrechtelijke-noodvoorziening-voor-samenlever-in.58617.lynkx>). Zie ook Notariaat Magazine, oktober 2013 naar aanleiding van de Taxenceblog. Het onderhavige stuk betreft een korte compilatie van genoemde bijdragen.

3. Dankbaar put ik wat deze cijfers betreft uit het rapport 'Koude uitsluiting' van het Netherlands Institute for Law and Governance (M.V. Antokolskaia, B. Breederveld, J.E. Hulst, W.D. Kolkman, F.R. Salomons en L.C.A. Verstappen), november 2010, p. 87 e.v. Slechts 'ruim de helft' van alle ongehuwde paren regelt hun vermogensrechtelijke relatie door middel van een notarieel samenlevingscontract, aldus het rapport, p. 89. Het ongehuwd samenwonen zal toenemen, zo is de verwachting. 
gemaakt velen ook geen testamenten zullen hebben. En de praktijk leert dat het fout kan gaan. ${ }^{4}$

\section{Een denkraam}

Bij het denken over de erfrechtelijke positie van de informele samenlevingspartner is een denkraam van groot belang. Als belangrijke punten gelden:

- het testamentaire walhalla;

- de te regisseren rechtszekerheid;

- het adagium: 'overlijden is ook scheiden';

- de vermoedelijke erfrechtelijke wil;

- de partijautonomie.

Vooraf moet worden opgemerkt dat Nederland testamentair bezien al tien jaar een walhalla is voor samenwoners. De langstlevende partner kan in de watten worden gelegd en afstammelingen kunnen met artikel 4:82 BW voorlopig monddood worden gemaakt. Artikel 4:82 BW krijgt van samenlevend Nederland de erfrechtelijke hoofdprijs van het afgelopen decennium, zo schat ik in. ${ }^{5}$ Maar ik focus thans op de informele partner, de partners die zelf niets geregeld hebben.

Indien men de informele partner een betere positie zou willen geven in ons erfrecht, dan zou wel eens de vraag kunnen luiden: 'Is-"ie" het wel, of is-"ie" het niet?' Komt bij een eventuele ingreep de rechtszekerheid niet in het geding? De rechtszekerheid verdient bijzondere aandacht indien de wens bestaat om de langstlevende informele partner in artikel 4:10 BW tot versterferfgenaam te bombarderen. Gelet op het feit dat een formeel begin en einde ontbreken en in ons systeem erfopvolging goederenrechtelijk van aard is, zijn kritische vragen betreffende de rechtszekerheid op dit punt zeker terecht. Maar waar een wil is, is een weg. Als al gedacht zou worden aan een eigen positie in het versterferfrecht, is wellicht een 'verbintenisrechtelijk erfgenaamschap' de oplossing. En met het leerstuk van het 'voorwaardelijk erfgenaamschap', waarbij aansluiting gezocht kan worden, kunnen wij thans toch ook goed overweg. Ik wijs in dit kader nog op de Algemene nabestaandenwet (Anw), een wet die erfrechtelijke trekjes vertoont (aanspraken bij overlijden) en waar in artikel 3 lid 2 tot en met 4 het volgende is geregeld:

'2. In deze wet en de daarop berustende bepalingen wordt als gehuwd of als echtgenoot mede aangemerkt de ongehuwde meerderjarige die met een andere ongehuwde meerderjarige een gezamenlijke huishouding voert, tenzij het betreft een bloedverwant in de eerste graad. (...)

3. Van een gezamenlijke huishouding is sprake indien twee personen hun hoofdverblijf in dezelfde woning hebben en zij blijk geven zorg te dra-

4. Zelfs bij beroemdheden. Zie T.J. Mellema-Kranenburg, De erfenis van Stieg Larsson: een projectie naar het Nederlandse erfrecht, TE 2009, nr. 6.

5. Anton Heyboer mocht dit evenwel niet baten, zie W.D. Kolkman, Vier levensgezellen, twee legitimarissen en een kunstenaar, TE 2007, nr. 2. gen voor elkaar door middel van het leveren van een bijdrage in de kosten van de huishouding dan wel anderszins.

4. Een gezamenlijke huishouding wordt in ieder geval aanwezig geacht, indien de betrokkenen hun hoofdverblijf hebben in dezelfde woning en:

a. zij met elkaar gehuwd zijn geweest of eerder voor de toepassing van deze wet daarmee gelijk zijn gesteld;

b. uit hun relatie een kind is geboren of erkenning heeft plaatsgevonden van een kind van de een door de ander;

c. zij zich wederzijds verplicht hebben tot een bijdrage aan de huishouding krachtens een geldend samenlevingscontract; of

d. zij op grond van een registratie worden aangemerkt als een gezamenlijke huishouding die naar aard en strekking overeenkomt met de gezamenlijke huishouding bedoeld in het derde lid.'

De informele partner is hier al mooi ingekaderd. Maar zelfs in ons huidige erfrecht komt de informele partner voor, en wel in het nooderfrecht van artikel 4:28 BW, waar het recht op 'voortgezette bewoning en voortgezet gebruik inboedel' ook bestaat voor degenen die tot diens overlijden met de overledene een duurzame gemeenschappelijke huishouding hadden. Hoewel de omvang van deze (quasi-)erfrechtelijke aanspraken beperkt is, blijkt dat niets onmogelijk is. Een blik over de grenzen leert dat overigens ook. ${ }^{6}$

Hoe dit ook zij, de rechtszekerheid is goed te regisseren en het rechtszekerheidsvraagstuk moet ons niet weerhouden verder te denken.

De vervolgvraag is echter waarom de informele partner een betere positie zou moeten krijgen? Wellicht is het een kwestie van smaak. De een zal meer focussen op de eigen erfrechtelijke verantwoordelijkheid van de burger, de ander ziet de overheid graag een handje helpen. Wel geldt dat de samenlevingsrelatie maatschappelijk gezien volledig geaccepteerd is en de wetgever heeft op diverse andere terreinen wél, met ruime partnerbegrippen, wettelijke aandacht voor het niet- geformaliseerd samenleven. Artikel 2 Anw en artikel 4:28 BW zijn daar mooie voorbeelden van.

Ik ben van mening dat een erfrechtelijke upgrading van de informele partners vereist is, mede gelet op de cijfers. De vraag is dan wel hoe dit vorm zou moeten krijgen en wat de grondslag is voor een verbeterde positie. Van belang bij de beantwoording van deze vraag is het adagium 'Overlijden is ook scheiden.' Voor echtgenoten geldt dat als ze uit elkaar gaan er alimentatie verschuldigd kan zijn. Gaat een echtpaar ongewild uiteen doordat een van tweeën overlijdt, dan sluit daarbij aan dat er ook erfrechtelijke alimentaire aanspraken gelden, in het geval de langstlevende in de knoei mocht komen door erfrechtelijk optreden van de eerststervende. Dit alimentaire vangnet wordt gevormd door de andere wettelijke rech-

6. Zie mijn bijdragen in noot 2 . 
ten (art. 4:28 e.v. BW). Daarentegen geldt voor samenwoners dat bij scheiding (vooralsnog) geen recht op alimentatie bestaat. Als uitgangspunt geldt dat bij samenwoners de postrelationele solidariteit - dat ook bij het einde van de relatie voor elkaar een zorgplicht geldt ontbreekt. ${ }^{7} \mathrm{Bij}$ dit uitgangspunt past niet dat er voor samenwoners wel een dwingende postmortale solidariteit zou moeten gelden in de vorm van dwingendrechtelijke (andere wettelijke erfrechtelijke) rechten.

Mocht er in de toekomst door de wetgever anders worden gedacht over alimentatie voor de samenlever, dan ligt het voor de hand om die lijn door te trekken in het erfrecht en de door mij voorgestane andere wettelijke rechten ook dwingend te laten werken voor deze ongehuwde stellen. Toch ben ik voor ingrijpen door de wetgever. De vermoedelijke erfrechtelijke mil, waarop ook het versterferfrecht voor gehuwden is gebaseerd, vormt hiervoor de grondslag. Heeft iemand die jaren ${ }^{8}$ samenwoont het niet beter voor met zijn partner dan met verre 'versterferfrechtelijke' verwanten als bijvoorbeeld zijn achterneven? Moeten de kinderen de informele langstlevende samenlever zomaar op straat kunnen zetten en de langstlevende verwijzen naar de algemene middelen?

\section{Een voorstel}

Om een balans te vinden tussen eigen verantwoordelijkheid, partijautonomie en de vermoedelijke wil pleit ik voor een regeling waarbij aangesloten wordt bij de andere wettelijke rechten voor echtgenoten, zodat ook de langstlevende informele partner voor de verzorging het vruchtgebruik kan claimen van de nalatenschap. De regeling dient evenwel niet dwingend van aard te zijn, gelet op onder meer het ontbreken van een wettelijk alimentatieregime. Wordt bemust gekozen voor een informele relatie om erfrechtelijk vrij te blijven, dan is er een bemuste erfrechtelijke wil, en dan zou het mogelijk moeten zijn het erfrechtelijke noodregime uit te sluiten. Kortom, testamentaire opting-out is toegestaan.

Boek 4 BW wordt daarmee het samenleverstijdperk ingeloodst. Erfrechtelijke kou wordt het gevolg van bewust handelen en niet van onwetendheid, de partijautonomie blijft intact, en er resteert - gelet op het feit dat de regeling slechts een noodvoorziening betreft een prikkel om eigen verantwoordelijkheid te nemen en te testeren.
7. Kamerstukken II 2011/12, 28 867, nr. 29, de later teruggetrokken motie van Anker, Timmer en De Wit, Kamerstukken II 2007/08, 28 867, nr. 20 en het rapport 'Koude uitsluiting' van het Netherlands Institute for Law and Governance (M.V. Antokolskaia e.a.), november 2010.

8. Hoelang men zou moeten samenleven, laat ik thans graag in het midden. Art. 4:30b lid 1 BW op Curaçao luidt als volgt: 'Heeft de erflater onmiddellijk voorafgaande aan zijn overlijden tien jaren of langer samengeleefd met een ander als waren zij gehuwd, dan kan de rechter, indien dat redelijk is, bepalen dat de ander voor de toepassing van deze afdeling [("de andere wettelijke rechten"); FS] met een echtgenoot gelijkgesteld wordt.'

\section{Tot slot}

Ik zie uit naar nog een decennium nieuw erfrecht en ik ben benieuwd of en hoe over tien jaar de informele samenlevingspartner in de erfrechtelijke schijnwerpers staat. 